\title{
PENGEMBANGAN MODEL PEMBELAJARAN KOOPERATIF TIPE ANALOGI SETTING SISTEM NGAYAH DENGAN ASESMEN PORTOFOLIO BENTUK FORMATIF UNTUK SISWA KELAS X TEKNIK MESIN
}

\author{
Oleh \\ K. S. Suardana, I N. Natajaya, Ni K. Widiartini \\ Program Studi Penelitian dan Evaluasi Pendidikan, Program Pasca Sarjana \\ Universitas Pendidikan Ganesha \\ Singaraja, Indonesia
}

e-mail: (sura.suardana, nyoman.natajaya, ketut.widiartini)@pasca.undiksha.ac.id

\begin{abstract}
Abstrak
Penelitian ini bertujuan untuk mengembangkan model pembelajaran kooperatif tipe analogi setting sistem ngayah dengan asesmen portofolio bentuk formatif untuk siswa kelas $\mathrm{X}$ program keahlian teknik mesin SMKN 3 Singaraja pada mata pelajaran pekerjaan dasar teknik mesin. Pengembangan model pembelajaran dalam penelitian ini mengacu pada model prototyping menurut Nieveen yang dimulai dari (a) tahap studi pendahuluan, (b) tahap prototiping yang mencakup tahap desain, tahap evaluasi dan revisi, dan (c) tahap penilaian yang mencakup tahap ujicoba untuk menentukan penilaian kepraktisan model pembelajaran yang dikembangkan. Melalui proses pengembangan, telah dihasilkan: (1) sintaks, terdiri dari 6 fase, yakni: menyampaikan tujuan dan memotivasi siswa, mengorganisasi siswa kedalam kelompok belajar dan membagikan lembar kerja, menyajikan informasi dan melibatkan siswa dalam memahami konsep rujukan dan memperkenalkan konsep target, membimbing kelompok belajar dan bekerja sesuai konsep rujukan dan memodifikasi sesuai konsep target secara tolong menolong atau berbagi, menarik kesimpulan dan mengevaluasi, dan memberikan penghargaan, (2) sistem sosial, siswa aktif belajar dan bekerja, dapat bekerjasama, tolong menolong dan berbagi antar anggota kelompok, (3) prinsip reaksi, guru berperan sebagai fasilitator dan moderator, (4) sistem pendukung adalah RPP, job sheet dan asesmen portofolio, (5) dampak instruksional dan pengiring, terjadi peningkatan proses dan aktivitas siswa mengerjakan tugas-tugas prakteknya dan muncul sikap positif siswa terhadap pembelajaran praktek, serta terbentuknya budaya gotong royong. Berdasarkan analisis uji coba terbatas, hasil penelitian ini menunjukkan bahwa model pembelajaran kooperatif tipe analogi setting sistem ngayah beserta perangkat pendukung pembelajaran telah memenuhi kriteria valid dan praktis.
\end{abstract}

Kata kunci: pengembangan, pembelajaran kooperatif tipe analogi, sistem ngayah, portofolio

\begin{abstract}
This research aimed to develop Cooperative Learning Model Development of Ngayah system setting analogy type with Formative Portfolio assessment for $10^{\text {th }}$ grade students of mechanical engineering program in SMKN 3 Singaraja in mechanical engineeringbasic lesson. Learning model development was based on prototyping model by Nieveen, started from (a) preliminary study stage, (b) prototyping stage, covers design stage, evaluation and revision stage, and (c) scoring stage, includes trials stage to determine learning model practicality scoring developed. Through development process, it produced: (1) syntax,consists of 6 phases, namely: conveying purposes and motivating students, organizing students into groups and distributing work sheets, providing information and involving the students in comprehending reference conceptand introducing target concept, guiding learning groups and working based on reference concept and modifying based on target concept by mutual helping or sharing, drawing conclusion and evaluating, and giving reward (2) social system, the students were actively learning and working and also be able to cooperate, to do mutual help, and to share between members. (3) reaction principal, the teacher was as facilitator and moderator, (4) supporting systems were lesson
\end{abstract}


plan, job sheet and portfolio assessment, (5) instructional and adherent impact, there was process improvement and student's activities in their practical tasks and students positive attitude toward practical learning, and also creating mutual cooperation culture. Based on limited trials analysis, the result of research shows that Cooperative Learning Model Development of Ngayah system setting analogy typewith its supporting tools has fulfilled valid and practicality criteria.

Keywords: analogy type of cooperative learning, development, Ngayah system, portfolio

\section{PENDAHULUAN}

\begin{tabular}{lr}
\multicolumn{2}{c}{ Undang-undang Sistem Pendidikan } \\
Nasional mengatur bahwa pendidikan \\
nasional berfungsi mengembangkan
\end{tabular} kemampuan dan membentuk watak serta peradaban bangsa yang bermartabat dalam rangka mencerdaskan kehidupan bangsa, bertujuan untuk berkembangnya potensi peserta didik agar menjadi manusia yang beriman dan bertakwa kepada Tuhan Yang Maha Esa, berakhlak mulia, sehat, berilmu, cakap, kreatif, mandiri, dan menjadi warga negara yang demokratis serta bertanggung jawab (Depdiknas, 2003). Untuk itu, sesuai Undang-undang Sistem Pendidikan Nasional, di tingkat sekolah menengah, selain sekolah menengah umum (SMA) juga dibuka sekolah menengah kejuruan (SMK) dengan berbagai program. Selanjutnya, di tingkat pendidikan tinggi, selain jalur akademik, juga dibuka jalur vokasional (politeknik) dengan berbagai program studi yang mana lulusannya diharapkan siap memasuki dunia kerja. Lulusan SMK diharapkan langsung bekerja, namun kenyataan menunjukkan bahwa lulusan SMK justru banyak yang menganggur. Kondisi ini menimbulkan berbagai pertanyaan. Pertama, apakah SMK yang didirikan tidak relevan dengan dunia kerja setempat yang akan menggunakan lulusannya. Pertanyaan kedua, apakah kurikulum yang berlaku di SMK belum mampu memberikan kompetensi kepada lulusan yang relevan dengan tuntutan dunia kerja. Pertanyaan berikutnya, apakah proses pembelajaran dan sarana pra-sarana pendukung pembelajaran belum mampu menghasilkan lulusan yang memiliki kompetensi sesuai dengan tuntutan kurikulum.
Relevansi SMK dengan kebutuhan tenaga dari dunia kerja setempat kurang logis untuk dipermasalahkan. Alasannya, pendirian SMK sudah didahului dengan studi kelayakan, yang mana di dalamnya terdapat kajian tentang kompetensi lulusan yang diperlukan dunia kerja setempat. Demikian juga relevansi kurikulum dengan kompetensi lulusan yang diharapkan dunia kerja setempat juga kurang logis untuk dipermasalahkan. Alasannya, penyusunan kurikulum SMK sudah melibatkan pakar kependidikan, pakar bidang ilmu dan teknologi yang sesuai dengan keahlian yang diharapkan, pengambil kebijakan, dunia kerja, serta tokoh-tokoh masyarakat. Demikian juga sarana dan pra-sarana standar sudah menjadi persyaratan dalam pendirian SMK dan secara kontinyu berupaya dilengkapi oleh pemerintah bersama pihak pengelola. Rupanya pertanyaan terkait proses pembelajaran yang masih sangat mendesak untuk dikaji.

Pembelajaran pendidikan kejuruan merupakan pembelajaran yang sarat dengan keterampilan psikomotorik. Karakteristik SMK yang menekankan penguasaan kompetensi keterampilan (skill) menuntut penerapan model pembelajaran yang lebih mampu menghasilkan kompetensi di bidang keterampilan. Dalam kesempatan seperti ini, sangat tepat kiranya untuk mengembangkan model pembelajaran yang sesuai dengan karakteristik materi pelajaran produktif yang ada di SMK. Model pembelajaran yang dapat menjadikan peserta didik aktif dalam kegiatan pembelajaran adalah model pembelajaran kooperatif tipe analogi dengan mengadopsi pembelajaran berbasis budaya lokal, yang sudah terbukti mampu mewariskan kompetensi di bidang 
keterampilan dari satu generasi ke generasi berikutnya.

Model pembelajaran kooperatif, merupakan model pembelajaran yang mengutamakan kinerja kelompok, dimana model pembelajaran kooperatif memberikan bukti nyata pada proses pembelajaran, model pembelajaran kooperatif menuntut diterapkannya pendekatan belajar siswa sentris, humanistik dan demokratis yang disesuaikan dengan kemampuan siswa dan lingkungan belajarnya. Menurut Eggen and Kauchak (dalam Trianto, 2010:58) pembelajaran kooperatif merupakan sebuah kelompok strategi pengajaran yang melibatkan siswa bekerja secara berkolaborasi untuk mencapai tujuan bersama. Pembelajaran kooperatif disusun dalam sebuah usaha untuk meningkatkan partisipasi siswa, memfasilitasi siswa dan pengalaman sikap kepemimpinan dan membuat keputusan dalam kelompok, serta memberikan kesempatan pada siswa untuk berinteraksi dan belajar bersama-sama siswa yang berbeda latar belakangnya. Pembelajaran kooperatif (cooperative learning) merupakan bentuk pembelajaran dengan cara siswa belajar dan bekerja dalam kelompok-kelompok kecil secara kolaboratif yang anggotanya sendiri terdiri dari empat sampai enam orang dengan struktur kelompok yang bersifat haterogen. Sedangkan Johnson and Johnson ( dalam Rusman, 2012:55) menyatakan bahwa tujuan pokok belajar kooperatif adalah memaksimalkan belajar siswa untuk peningkatan prestasi akademik dan pemahaman baik secara individu maupun secara kelompok. Karena siswa bekerja dalam suatu kelompok maka dengan sendirinya dapat memperbaiki hubungan diantara para siswa dari berbagai latar belakang etnis dan kemampuan. Dengan belajar kooperatif diharapkan kelak akan muncul generasi baru yang memiliki prestasi akademik yang cemerlang dan memiliki solidaritas sosial yang kuat.

Pendekatan analogi memberikan kesempatan yang lebih luas kepada peserta didik menggunakan analogi sebagai dasar penalaran dan melatih kemandirian yang dimilikinya sehingga prestasinya bisa ditingkatkan. Proses pembelajaran bukan hanya mentransfer pengetahuan guru kepada siswa, tetapi juga mengajar siswa bagaimana mengenali dan menganalisa hubungan antara pengetahuan baru dengan pengetahuan siswa sebelumnya, sehingga ini dapat melatih siswa untuk berpikir lebih kreatif, menggunakan penalaran dan kemandirian serta menumbuhkan rasa percaya diri dalam mengungkapkan argument sesuai dengan kemampuan yang dimilikinya. Menurut Suparno (2007: 151) analogi adalah model untuk penjelasan suatu konsep atau peristiwa dengan menganalogikan suatu konsep atau peristiwa baru tersebut dengan suatu peristiwa yang mudah dimengerti atau pernah dialami siswa. Berpikir analogi adalah keterampilan berpikir tentang sesuatu hal baru yang diperoleh dari suatu hal yang telah diketahuinya sebelumnya dengan memperhatikan persamaan antara dua hal tersebut. Analogi yang baik dapat memudahkan pemahaman dan pengingatan (mengingat kembali) tentang sesuatu yang telah dipelajari.

Pembelajaran berbasis budaya diharapkan dapat menghasilkan kompetensi dalam satu kesatuan teori dan praktek. Kompetensi tersebut diharapkan muncul dalam pola pikir, sikap dan perilaku di masyarakat dan terwariskan secara kontinyu dari generasi ke generasi berikutnya. Pembelajaran berbasis budaya diharapkan terjadi dalam kolaborasi yang mengedepankan interaksi sosial. Dengan demikian siswa terbiasakan untuk hidup dalam kehidupan sosial masyarakat yang majemuk didasari nilai-nilai luhur untuk kebersamaan. Simpati dan empati juga diharapkan tumbuh dari interaksi sosial, sehingga siswa kita terlepas dari berbagai konflik sosial. Dengan demikian akan terwujud ungkapan Banks \& Banks (2005) bahwa segala sesuatu yang terjadi dalam pendidikan berkaitan dengan budaya, baik dalam hal pengakuan, 
transforasinya, maupun penciptaanya.

Proses pembelajaran berbasis budaya memberikan kesempatan kepada siswa untuk mengemukakan pendapat atau pertanyaan yang mencerminkan rasa keingintahuan mereka yang tinggi. Selain itu, siswa juga diberi kesempatan untuk terlibat dalam proses eksplorasi, elaborasi, dan analisis yang kreatif untuk mencari jawaban. Pada akhirnya, pembelajaran berbasis budaya memberi kesempatan kepada siswa terlibat dalam proses pengambilan kesimpulan serta melakukan konfirmasi. Aktivitas dalam pembelajaran berbasis budaya dirancang bukan hanya untuk mengaktifkan siswa, melainkan dirancang untuk memfasilitasi terjadinya interaksi sosial dan negosiasi makna sampai terjadinya penciptaan makna. Kebermaknaan dalam hal ini diperoleh dari hasil interaksi sosial dan negosiasi antara pengetahuan yang dimiliki oleh siswa dan informasi baru yang diperolehnya dalam pembelajaran, antara siswa dan siswa lainnya, antara siswa dan guru dalam konteks komunitas budaya.

Pembelajaran kooperatif tipe analogi yang digunakan dalam penelitian ini diadopsi dari model kerja pada sistem ngayah. Model pembelajaran yang ada dalam sistem ngayah atau ngoopin telah berhasil membelajarkan keterampilan membuat sarana upacara keagamaan dan keterampilan lainnya. Ngayah merupakan model gotong royong dalam masyarakat Bali. Ngayah ditujukan untuk tolongmenolong, berbagi, bersosialisasi yang menunjukkan solidaritas anggota masyarakat. Ngayah lebih mengacu pada kegiatan bersama untuk kegiatan organisasi yang besar

Ngayah tidak semata-mata gotong royong, melainkan mencerminkan tanggung jawab religius serta kebajikan sosial dalam budaya Bali. Ngayah bukan sekedar perintah dari kehidupan beragama atau perintah dari kehidupan sosial, melainkan sebagai manifestasi dari rasa tulus iklas untuk berbakti kepada Tuhan atau mengabdi kepada komunitas masyarakat dan negara. Kata ngayah dalam kamus Bali-Indonesia (1990) diartikan melakukan pekerjaan tanpa mendapat upah. Ngayah adalah kewajiban sosial masyarakat Bali yang dilaksanakan dengan hati yang tulus iklas serta penuh tanggung jawab dilandasi semangat gotong royong baik di tempat suci maupun di tempat kegiatan sosial lainnya, seperti banjar atau subak.

Ngayah juga diartikan sebagai metode menyumbang dalam kehidupan sosial masyarakat Bali (Kompasiana, 2015). Sumbangan yang diberikan dalam bentuk tenaga, keahlian, atau keterampilan. Warga masyarakat memberi sumbangan tenaga, keahlian, atau keterampilan yang dimiliki secara tulus iklas saat penyiapan perangkat upacara di tempat suci. Demikian pula hal yang dilakukan warga saat ngayah untuk kegiatan lain di balai banjar atau di subak. Tanpa memperhatikan apa yang dilakukan warga yang lain, setiap warga melakukan kegiatan yang mampu dilakukan. Situasi kebersamaan dan sepenanggungan tampak jelas dalam situasi ngayah. Raut muka warga yang terlibat ngayah semua memancarkan ketulusan dan keiklasan, serta tidak memikirkan imbalan (pamrih).

$\begin{array}{llr}\text { Pendidikan } & \text { kejuruan memiliki } \\ \text { karakteristik yang } & \text { berbeda dengan } \\ \text { mendidikan umum. Dalam pendidikan }\end{array}$ kejuruan proses dan hasil pembelajaran lebih cenderung dalam bentuk kompetensi. Kompetensi adalah atribut individu peserta didik, sehingga asesmen berbasis kompetensi bersifat individual. Budiastuti (dalam Kustitik, 2016) menyatakan bahwa sistem penilaian yang tepat untuk mengukur kompetensi peserta didik dalam pendidikan kejuruan adalah performance based assessment atau authentic assessment yang dilakukan secara menyeluruh, mencakup aspek kognitif, afektif, dan psikomotor yang dilakukan secara simultan. Melalui penilaian autentik diharapkan dapat merangsang peserta didik untuk mengembangkan keterampilan atau 
kompetensi yang relevan dengan dunia kerja.

Mata pelajaran pekerjaan dasar teknik mesin (PDTM) merupakan salah satu mata pelajaran yang menitik beratkan hasil dari suatu proses pembelajaran berdasarkan kegiatan yang dilakukan oleh peserta didik, dengan kata lain yang dinilai dalam aktivitas pembelajaran peserta didik adalah proses dan produk yang telah dicapai peserta didik dalam kegiatan praktek. Pelaksanaan penilaian dapat dilakukan secara langsung pada saat peserta didik melakukan aktivitas belajar, maupun secara tidak langsung melalui bukti hasil belajar sesuai dengan kriteria kinerja atau performance criteria. Oleh karena itu sistem penilaian untuk mata pelajaran pekerjaan dasar teknik mesin dapat menggunakan asesmen portofolio. Asesmen portofolio adalah suatu prosedur pengumpulan informasi mengenai perkembangan dan kemampuan siswa melalui portofolionya, dimana pengumpulan informasi tersebut dilakukan secara formal dengan menggunakan kriteria tertentu, untuk tujuan pengambilan keputusan terhadap status siswa. Portofolio adalah kompilasi bukti menunjukkan kemajuan akademik, prestasi, ketrampilan, dan sikap. Ditambahkan bahwa bukti pada portofolio dikoleksi pada periode tertentu.

Suherman (2007:27) mendefinisikan portofolio sebagai kumpulan bukti fisik kinerja (individu atau kelompok) sebagai data otentik dari aktivitas yang dilakukan. Portofolio merupakan kumpulan (koleksi) pekerjaan siswa terbaik atau karya siswa yang paling berarti sebagai hasil kegiatan belajarnya pada suatu bidang (mata pelajaran) tertentu. Koleksi pekerjaan siswa tersebut didokumentasikan secara baik dan teratur sehingga dapat mewakili suatu sejarah belajar dan demonstrasi pencapaian sesuatu secara terorganisasi (Manahal 2001:10). Jadi asessmen portofolio adalah kumpulan bukti fisik kinerja (individu atau kelompok) yang didokumentasikan secara baik dan teratur sehingga dapat mewakili suatu sejarah dari aktivitas yang dilakukan.

Asesmen portofolio mengandung tiga elemen pokok yaitu: (1) sampel karya siswa, (2) evaluasi diri, dan (3) kriteria penilaian yang jelas dan terbuka (Dantes, 2008). Menurut Dantes (2008:15); Marhaeni (2005) mancatat bahwa sampel karya siswa merupakan bukti (evidence) yang menunjukkan perkembangan belajarnya dari waktu ke waktu. Sampel tersebut dapat berupa tulisan/karangan, audio atau video, laporan, problem matematika, maupun eksperimen. Karya tersebut disusun secara sistematis tergantung pada tujuan pembelajaran, preferensi guru, maupun preferensi siswa. Asesmen portofolio menilai proses maupun hasil. Oleh karena itu proses dan hasil sama pentingnya. Meskipun asesmen ini bersifat berkelanjutan, yang berarti proses mendapatkan porsi penilaian yang besar (bandingkan dengan asesmen konvensional yang hanya menilai hasil belajar) tetapi kualitas hasil sangat penting. Dan memang, penilaian proses yang dilakukan tersebut sesungguhnya memberi kesempatan siswa mencapai produk yang sebaik-baiknya.

Berbagai bukti fisik selama asesmen berlangsung disimpan dalam folder (seringkali dipakai map, amplop besar, locker, kardus yang diisi nama masingmasing siswa). Bukti fisik diperoleh dari hasil tes maupun non-tes (tes objektif diupayakan minimal). Bukti fisik non-tes antara lain karya (artefak), rekaman, draf, kinerja, dan lain-lain yang dapat menunjukkan perkembangan siswa sebagai siswa. Catatan dan bahan evaluasi-diri juga merupakan bagian dalam folder.

Mengenai kriteria penilaian, juga ada dalam evaluasi diri. Bila pada praktik asesmen konvensional kriteria penilaian menjadi 'rahasia' guru atau pun penguji, dalam asesmen portofolio kriteria penilaian justru harus disosialisasikan kepada siswa secara jelas. Hal ini sangatlah logis dan manusiawi. Bagaimana seseorang bisa memenuhi target yang dibebankan 
padanya, jika target tersebut tidak secara jelas dia ketahui? Bahkan, cara mencapai target itu pun harus diketahuinya agar dapat dia tentukan strategi yang tepat, bagaimana cara mencapai target tersebut dengan waktu, biaya, dan tenaga yang seefektif dan seefisien mungkin. Demikian yang mesti terjadi dalam asesmen otentik.

Karena itu, kriteria penilaian harus mencakup prosedur dan standar penilaian. Para ahli menganjurkan agar sistem dan standar asesmen tersebut ditetapkan bersama-sama dengan siswa, atau paling tidak diumumkan secara jelas.

O'Malley dan Valdez Pierce (dalam Suherman 2007:30) bahkan mengatakan bahwa 'self-assessment is the key to portfolio'. Hal ini disebabkan karena melalui evaluasi diri siswa dapat membangun pengetahuannya serta merencanakan dan memantau perkembangannya apakah rute yang ditempuhnya telah sesuai. Melalui evaluasi diri siswa dapat melihat kelebihan maupun kekurangannya, untuk selanjutnya kekurangan ini menjadi tujuan perbaikan (improvement goal). Dengan demikian siswa lebih bertanggungjawab terhadap proses belajarnya dan pencapaian tujuan belajarnya.

Asesmen portofolio adalah asesmen autentik yang paling komprehensif dalam khasanah asesmen otentik karena melibatkan jenis-jenis asesmen yang lain seperti asesmen kinerja, asesmen diri, projek, esai, dan juga tes objektif. Semua hasil asesmen tersebut, jika diatur secara sistematis mulai dari tujuan asesmen (berdasarkan KD dan indikator), serta mengikuti langkah-langkah implementasi seperti yang disebutkan di atas, dan mengandung ketiga elemen pokok asesmen portofolio (karya, kriteria penilaian, dan asesmen diri), maka sudah merupakan praktik asesmen portofolio. Penilaian formatif adalah evaluasi yang dilaksanakan di tengah-tengah atau pada saat berlangsungnya proses pembelajaran, yaitu dilaksanakan pada setiap kali satuan pembelajaran atau subpokok bahasan dapat diselesaikan dengan tujuan untuk mengetahui sejauh mana peserta didik "telah terbentuk" sesuai dengan tujuan pengajaran yang telah ditentukan. Dengan demikian dalam penelitian ini, akan dikembangkan model pembelajaran kooperatif tipe analogi setting sistem ngayah dengan asesmen portofolio bentuk formatif untuk siswa kelas $X$ program keahlian teknik mesin SMKN 3 Singaraja pada mata pelajaran pekerjaan dasar teknik mesin. Penelitian pengembangan ini bertujuan untuk (1) merumuskan model pembelajaran kooperatif tipe analogi setting sistem ngayah dengan asesmen formatif portofolio yang mencakup sintak, sistem sosial, prinsip reaksi, sistem pendukung, dan dampak instruksional dan pengiring. (2) mendeskripsikan validitas model pembelajaran kooperatif tipe analogi setting sistem ngayah dengan asesmen portofolio dalam bentuk penilaian formatif.

\section{METODE PENELITIAN}

Penelitian ini merupakan penelitian pengembangan atau development research. Produk yang akan dikembangkan yaitu model pembelajaran kooperatif tipe analogi setting sistem ngayah beserta perangkat pendukung pembelajaran yang meliputi Rencana Pelaksanaan Pembelajaran (RPP), Job Sheet, dan asesmen portofolio. Model pengembangan yang digunakan dalam penelitian ini mengacu pada model prototyping menurut Nieveen yang meliputi (1) preliminary research, (2) prototyping stage, dan (3) assessment stage. Uji pakar melibatkan 2 orang pakar untuk menentukan kevalidan model pembelajaran. Uji coba produk dengan melibatkan 35 siswa kelas $X$ program keahlian teknik mesin dan seorang guru di SMKN 3 Singaraja.

Prosedur pengembangan model pembelajaran kooperatif tipe analogi setting sistem ngayah meliputi tahap studi pendahuluan, tahap prototiping, dan tahap penilaian. Pada tahap studi pendahuluan dilakukan kajian literatur dan penelitian terdahulu yang terkait. Pada tahap ini juga dilakukan kegiatan prasurvei lapangan 
dengan memberikan angket pada guru, melakukan wawancara dengan guru, dan observasi proses pembelajaran. Informasi yang diperoleh digunakan sebagai bahan untuk perancangan produk pengembangan. Pada tahap prototiping, didesain suatu draf model pembelajaran kooperatif tipe analogi setting sistem ngayah yang mencakup sintak, sistem sosial, prinsip reaksi, sistem pendukung, dan dampak pembelajaran dan dampak pengiring, beserta perangkat pendukung yaitu berupa RPP, job sheet, dan instrumen asesmen portofolio, dan instrumen penilaian kualitas produk pengembangan. Selanjutnya draf model pembelajaran, perangkat pendukung beserta instrumen penilaian kualitas produk pengembangan dinilai oleh ahli untuk dinilai kevalidannya. Hasil penilaian ahli kemudian direvisi jika diperlukan, untuk mendapatkan produk yang valid yang siap untuk diujicobakan. Pada tahap penilaian, model pembelajaran yang sudah memenuhi kriteria valid diujicobakan pada pembelajaran pekerjaan dasar teknik mesin di kelas untuk mengetahui kepraktisan dari model pembelajaran yang dikembangkan. Instrumen yang digunakan dalam penelitian ini terdiri atas (1) instrumen kevalidan yaitu meliputi: (a) lembar penilaian kevalidan komponen model pembelajaran, dan (b) lembar penilaian perangkat pendukung pembelajaran (RPP, job sheet, asesmen portofolio), (2) instrumen penalian kepraktisan yaitu meliputi (a) angket kepraktisan dari guru, dan (b) angket penilaian dari siswa. Tingkat kevalidan model pembelajaran dan perangkat pendukung pembelajaran ditentukan oleh penilaian dua orang ahli/judges. Skor yang diperoleh dari lembar penilaian kevalidan dianalisis menggunakan formula Gregory. Kepraktisan pembelajaran yang dikembangkan diukur berdasarkan hasil penilaian dari guru dan siswa yang berkaitan dengan kemudahan penerapan model pembelajaran beserta perangkat pendukung pembelajaran di kelas. Skor yang diperoleh, kemudian dikonversikan menjadi data kualitatif skala lima,
(Candiasa, 2010:46) pada tabel 1. Model pembelajaran yang dikembangkan dikatakan praktis, jika penilaian dari guru dan siswa menunjukkan minimal berada pada kategori praktis.

Tabel 1. Kriteria Konversi Data Kuantitatif ke Data Kualitatif dengan Skala Lima

\begin{tabular}{|c|c|c|}
\hline Rentangan Skor & Nilai & Kategori \\
\hline $\mathrm{X} \geq \mathrm{Mi}+1,8 \mathrm{SDi}$ & $A$ & $\begin{array}{l}\text { Sangat } \\
\text { Baik }\end{array}$ \\
\hline $\mathrm{Mi}+1,8 \mathrm{SDi}>\mathrm{X} \geq \mathrm{Mi}+0,6 \mathrm{SDi}$ & B & Baik \\
\hline $\mathrm{Mi}+0,6 \mathrm{SDi}>\mathrm{X} \geq \mathrm{Mi}-0,6 \mathrm{SDi}$ & C & $\begin{array}{l}\text { Cukup } \\
\text { Baik }\end{array}$ \\
\hline Mi-0,6SDi>X $\geq$ Mi-1,8SDi & D & $\begin{array}{l}\text { Kurang } \\
\text { Baik }\end{array}$ \\
\hline $\mathrm{X}<\mathrm{Mi}-1,8 \mathrm{SDi}$ & $E$ & $\begin{array}{l}\text { Sangat } \\
\text { Kurang } \\
\text { Baik }\end{array}$ \\
\hline
\end{tabular}

HASIL PENELITIAN DAN PEMBAHASAN

Model pembelajaran yang dikembangkan dalam penelitian ini adalah model pembelajaran kooperatif tipe analogi setting sistem ngayah yang terdiri atas sintak, sistem sosial, prinsip reaksi, sistem pendukung, dan dampak instruksional dan pengiring. Berdasarkan hasil penilaian ahli terhadap kevalidan model pembelajaran kooperatif tipe analogi setting sistem ngayah dapat ditunjukkan bahwa komponen-komponen model pembelajaran kooperatif tipe analogi setting sistem ngayah secara keseluruhan tingkat validitas yang dicapai adalah 1,00 yang menunjukkan kriteria sangat tinggi. Hasil penilaian ahli terhadap kevalidan perangkat pendukung pembelajaran (RPP, job sheet, asesmen portofolio) tingkat validitas yang dicapai adalah 1,00 termasuk kriteria sangat tinggi. Komponen-komponen model pembelajaran kooperatif tipe analogi setting sistem ngayah, terdiri atas sintak, sistem sosial, prinsip reaksi, sistem pendukung, dan dampak instruksional dan pengiring. Sintak model pembelajaran kooperatif tipe analogi setting sistem ngayah terdiri atas (1) menyampaikan tujuan dan memotivasi siswa. Pada tahap ini, kegiatan dimulai 
dengan menjelaskan tujuan pembelajaran yang ingin dicapai pada pelajaran teknik penggunaan perkakas tangan dan mempersiapkan peserta didik siap belajar, selanjutnya guru menjelaskan pendekatan dan model pembelajaran yang digunakan serta metodenya dan melakukan tanya jawab sebagai motivasi belajar kepada peserta didik dengan mengaitkan antara pekerjaan yang ada di industri dengan pelajaran pekerjaan dasar teknik mesin. Hasil ujicoba model pembelajaran di sekolah yaitu selama tiga kali pertemuan, tahap menyampaikan tujuan dan memotivasi siswa dalam pembelajaran pekerjaan dasar teknik mesin dapat terlaksana pada keseluruhan pertemuan;(2) mengorganisasi siswa kedalam kelompok belajar dan membagikan lembar kerja. Pada tahap ini, aktivitas difokuskan pada pengkondisian siswa untuk belajar dalam kelompok, dimana kelompok belajar siswa telah tentukan oleh guru dengan kemampuan awal beragam, selanjutnya guru membagikan lembar kerja atau job sheet yang dipakai acuan dalam bekerja. Siswa juga dituntut untuk dapat menentukan peralatan yang dapat digunakan untuk dapat menyelesaikan benda kerjanya. Pada pertemuan pertama, persentase keterlaksanaan tahap mengorganisasi siswa kedalam kelompok belajar dan membagikan lembar kerja.yaitu sebesar $67 \%$. Hal tersebut dapat disebabkan siswa belum terbiasa untuk belajar secara berkelompok dengan anggota kelompok yang telah ditentukan oleh guru. Selain itu, hal lain yang mungkin menjadi sebab yaitu siswa belum terbiasa dan belum siap untuk menentukan peralatan praktek secara mandiri. Namun demikian, pada pertemuan- pertemuan selanjutnya tahap mengorganisasi siswa kedalam kelompok belajar dan membagikan lembar kerja dapat terlaksana dengan baik yang ditunjukkan dengan persentase keterlaksanaan mencapai $100 \%$; (3) menyajikan informasi dan melibatkan siswa dalam memahami konsep rujukan dan memperkenalkan konsep target. Pada tahap ini, guru memberikan gambaran/kisi-kisi, manfaat pembelajaran dari materi pembelajaran akan dipelajari serta memberikan sistematik penilaian yang akan digunakan. Guru menyampaikan materi mengenai jenis dan fungsi perkakas tangan serta prosedur pemeliharaan perkakas tangan kepada siswa dengan jalan demontrasi dan secara verbal. Guru menunjukkan contoh benda kerja ( klem C), dan bentuk benda kerja yang akan dibuat sesuai dengan lembar kerja(job sheet) yang telah disiapkan. Pada awalnya tahap menyajikan informasi dan melibatkan siswa dalam memahami konsep rujukan dan memperkenalkan konsep target belum dapat terlaksana secara baik, hal tersebut ditunjukkan dengan persentase keterlaksanaan hanya sebesar $67 \%$. Hal ini disebabkan masih ada siswa belum memahami secara keseluruhan materi menggunakan perkakas tangan. Namun demikian, pada pertemuan- pertemuan selanjutnya tahap ini dapat terlaksana secara 100\%; (4) membimbing kelompok belajar dan bekerja sesuai konsep rujukan dan memodifikasi sesuai konsep target secara tolong menolong atau berbagi. Pada tahap ini, siswa bersama anggota kelompoknya mulai belajar dan bekerja mengerjakan tugas mereka sesuai dengan tugas yang tertuang pada job sheet. Guru melakukan pembimbingan terhadap kelompok siswa dalam proses jalannya diskusi maupun dalam melaksanakan praktek. Dalam pelaksanaan pembelajaran untuk melihat kemajuan hasil belajar dan bekerja siswa setiap kelompok dengan menggunakan asesmen portofolio. Siswa yang sudah selesai dapat memberikan bantuan dengan iklas (ngayah) kepada teman dalam kelompoknya yang masih mengalami kesulitan dalam belajar baik teori maupun praktek. Siswa yang lebih pandai secara sukarela bisa membantu dengan memberikan contoh cara kerja kepada teman dalam kelompoknya yang masih mengalami kesulitan dalam menyelesaikan tugas-tugasnya. Pada pertemuan pertama belum dapat terlaksana 
secara baik, hal tersebut ditunjukkan dengan persentase keterlaksanaan hanya sebesar $50 \%$. Hal ini disebabkan masih ada siswa belum memahami secara keseluruhan cara menggunakan perkakas tangan yang baik dan efektif dan masih ragu dengan kemampuan temannya. Namun demikian, pada pertemuanpertemuan selanjutnya tahap ini dapat terlaksana secara 100\%; (5) menarik kesimpulan dan mengevaluasi. Pada tahap ini guru bersama dengan siswa melakukan refleksi atau evaluasi terhadap proses pembelajaran yang telah dilakukan siswa. Tahap ini guru membantu siswa untuk merefleksikan pengetahuan dan keterampilan ynag telah mereka peroleh, strategi pembelajaran yang siswa gunakan, dan kontribusi siswa dalam pembelajaran kelompok. Guru melaksanakan evaluasi hasil belajar siswa tentang materi yang telah dipelajari dengan menggunakan asesmen portofolio yang mencakup aspek tes formatif, kinerja, dan aktifitas siswa.Tahap menarik kesimpulan dan mengevaluasi pada awal pembelajaran hingga pertemuan ketiga dapat terlaksana secara 100\%.; dan (6) memberikan penghargaan. Pada tahap ini, guru memberikan penghargaan untuk menghargai baik upaya maupun hasil belajar individu dan kelompok. Tahap memberikan penghargaan pada awal pembelajaran hingga pertemuan ketiga dapat terlaksana secara $100 \%$.

Sistem sosial yang dikembangkan dalam pembelajaran kooperatif tipe analogi setting sistem ngayah ini mencakup peran dan hubungan siswa dan guru secara rinci pada setiap tahap pembelajaran. Sistem sosial pada tahap menyampaikan tujuan dan memotivasi siswa dan mengorganisasi siswa kedalam kelompok belajar dan membagikan lembar kerja adalah sangat terstruktur dan dikendalikan oleh guru. Pada tahap menyajikan informasi dan melibatkan siswa dalam memahami konsep rujukan dan memperkenalkan konsep target terjadi interaksi dan negosiasi yang kondusif antara guru dengan siswa serta siswa dengan siswa dalam kelompok belajarnya. Pada tahap membimbing kelompok belajar dan bekerja sesuai konsep rujukan dan memodifikasi sesuai konsep target secara tolong menolong atau berbagi, siswa berperan besar dalam aktivitas pembelajaran khususnya aktivitas dalam kelompoknya, sedangkan guru berperan sebagai fasilitator dan pembimbing. Pada tahap ini sistem sosial sangat demokratis, sepenuhnya dikendalikan oleh siswa. Berdasarkan analisis keterlaksanaan model pembelajaran kooperatif tipe analogi setting sistem ngayah dapat diketahui bahwa pada keseluruhan pembelajaran guru telah berperan sebagai fasilitator dan pembimbing yaitu dengan cara mengondisikan siswa untuk belajar, membantu siswa untuk mendefinisikan dan mengorganisasikan tugas belajar. Selanjutnya peran guru sebagai evaluator juga telah terlaksana pada keseluruhan pembelajaran pekerjaan dasar teknik mesin selama tiga kali pertemuan.

Prinsip reaksi berkaitan dengan peran guru dalam pembelajaran. Dalam pembelajaran kooperatif tipe analogi setting sistem ngayah, guru berperan sebagai fasilitator dan moderator. Sebagai fasilitator, guru menyediakan sumbersumber belajar, mendorong siswa untuk belajar, dan memberikan bantuan bagi siswa untuk dapat belajar dan mengkonstruksi pemahamannya secara optimal. Sebagai moderator, guru memimpin dan mengatur mekanisme diskusi kelas sehingga berjalan lancar.

Sistem pendukung yang diperlukan untuk dapat melaksanakan model pembelajaran kooperatif tipe analogi setting sistem ngayah adalah adalah RPP, job sheet dan asesmen portofolio. Job sheet untuk menunjang proses pembelajaran praktek menggunakan perkakas tangan sebagai acuan dalam bekerja.

Dalam model pembelajaran kooperatif tipe analogi setting sistem ngayah, komponen dampak instruksional yang diharapkan adalah tercapainya tujuan 
pembelajaran yang dirumuskan dalam kompetensi dasar yang diharapkan dan dioperasionalkan dalam indikator-indikator ketercapaian kompetensi dasar dan diukur dengan pedoman rumusan hasil belajar yang diharapkan. Ketercapaian indikator kompetensi dasar dilihat dari aktivitas siswa mengerjakan tugas-tugas prakteknya yang tertuang pada job sheet, sedangkan ukuran hasil belajar siswa melalui skor yang dicapai siswa dalam penilaian hasil belajar siswa menggunakan asesmen portofolio. Dampak pengiring yang muncul adalah sikap positif siswa terhadap pembelajaran praktek, serta terbentuknya budaya gotong royong, saling tolong-menolong, saling menghargai, berbagi, bersosialisasi yang menunjukkan solidaritas anggota kelompok.

Berdasarkan hasil uji coba model pembelajaran kooperatif tipe analogi setting sistem ngayah di di SMK Negeri 3 Singaraja pada siswa kelas $X$ Kompetensi Keahlian Teknik Mesin, dapat diketahui kepraktisan model pembelajaran kooperatif tipe analogi setting sistem ngayah.

Tabel 2. Skor dan Kriteria Hasil Penilaian Kepraktisan Model PembelajaranKooperatif Tipe Analogi Setting Sistem Ngayah dari Guru

\begin{tabular}{ccc}
\hline Pertemuan & Skor & Kriteria \\
\hline I & 45 & Praktis \\
II & 47 & Praktis \\
III & 47 & Praktis \\
\hline
\end{tabular}

Berdasarkan tabel di atas, dapat
ditunjukkan bahwa keseluruhan
pembelajaran, yaitu sebanyak 3 kali
pertemuan, tingkat kepraktisan model
pembelajaran menurut penilaian guru telah
memenuhi kriteria praktis, namun pada
setiap aspek penilaian kepraktisan dari guru
terdapat beberapa hal yang perlu
digarisbawahi. Dari tiga kali pertemuan,
sebanyak satu kali pertemuan
pembelajaran guru menyatakan ragu-ragu
dengan kemudahan langkah - langkah
pembelajaran kooperatif tipe analogi setting

sistem ngayah. Hal tersebut dapat dikarenakan guru belum terbiasa dengan model pembelajaran kooperatif tipe analogi setting sistem ngayah. Selain itu, waktu yang digunakan guru untuk mempelajari model pembelajaran ini juga cukup singkat, sehingga menyebabkan kurangnya persiapan dari guru yang berdampak pada pelaksanaan implmentasi model di kelas. Selanjutnya, dari segi pengaturan diskusi pada pertemuan pertama guru juga menyatakan ragu-ragu terhadap kemudahan pengaturan diskusi di kelas. Hal tersebut dimungkinkan siswa belum terbiasa untuk berdiskusi dengan anggota kelompok yang telah ditentukan oleh guru. Dari aspek kecukupan alokasi waktu yang mencakup alokasi waktu untuk diskusi, kegiatan praktek, generalisasi materi dan pemahaman materi pada setiap pertemuannya, guru menyatakan ragu-ragu pada alokasi waktu melaksanakan praktek. Hal ini disebabkan biasanya pelajaran praktek memerlukan alokasi waktu yang panjang. Selain itu, dari segi ketercapaian tujuan pembelajaran yang mencakup pencapaian kompetensi, presentasi dan diskusi siswa, evaluasi proses dan hasil belajar, guru juga telah menyatakan setuju pada keseluruhan pembelajaran dengan menggunakan model pembelajaran kooperatif tipe analogi setting sistem ngayah. Hasil penilaian kepraktisan dari siswa diperoleh skor aktual 8,17 yang menunjukkan bahwa model pembelajaran kooperatif tipe analogi setting sistem ngayah memenuhi kriteria sangat praktis dan jumlah persentase jawaban "ya" dari respon siswa sebesar $82 \%$.

\section{PENUTUP}

Berdasarkan rumusan masalah, hasil penelitian, dan pembahasan yang telah diuraikan, diperoleh kesimpulan sebagai berikut. (1) Model pembelajaran kooperatif tipe analogi setting sistem ngayah telah memenuhi kriteria valid dan praktis terdiri atas komponen-komponen sebagai berikut. (a) Sintak, terdiri atas langkah-langkah yaitu menyampaikan 
tujuan dan memotivasi siswa, mengorganisasi siswa kedalam kelompok belajar dan membagikan lembar kerja, menyajikan informasi dan melibatkan siswa dalam memahami konsep rujukan dan memperkenalkan konsep target, membimbing kelompok belajar dan bekerja sesuai konsep rujukan dan memodifikasi sesuai konsep target secara tolong menolong atau berbagi, menarik kesimpulan dan mengevaluasi, dan memberikan penghargaan. (b) Sistem sosial yang dibangun adalah pembelajaran yang demokratis, siswa aktif belajar dan bekerja serta dapat bekerjasama, tolong menolong dan berbagi antar anggota kelompok. (c) Prinsip reaksi yang terjadi guru berperan sebagai fasilitator yaitu menyediakan sumber-sumber belajar, mendorong siswa untuk belajar, dan memberikan bantuan bagi siswa untuk dapat belajar dan mengkonstruksi pemahamannya secara optimal dan sebagai moderator, guru memimpin dan mengatur mekanisme diskusi kelas sehingga berjalan lancar. (d) Sistem pendukung dalam pembelajaran kooperatif tipe analogi setting sistem ngayah adalah RPP, job sheet dan asesmen portofolio. (e) Dampak instruksional pembelajaran kooperatif tipe analogi setting sistem ngayah adalah ketercapaian indikator kompetensi dasar dilihat dari aktivitas siswa mengerjakan tugas-tugas prakteknya yang tertuang pada job sheet, sedangkan ukuran hasil belajar siswa melalui skor yang dicapai siswa dalam penilaian hasil belajar siswa menggunakan asesmen portofolio. Sedangkan dampak pengiringnya adalah sikap positif siswa terhadap pembelajaran praktek, serta terbentuknya budaya gotong royong, saling tolong-menolong, saling menghargai, berbagi, bersosialisasi yang menunjukkan solidaritas anggota kelompok. (2) Model pembelajaran kooperatif tipe analogi setting sistem ngayah yang mencakup sintak, sistem sosial, prinsip reaksi, dan dampak instruksional dan pengiring, dan perangkat pembelajaran berupa RPP, job sheet, dan asesmen portofolio telah mencapai kriteria validitas sangat tinggi. Kepraktisan model pembelajaran kooperatif tipe analogi setting sistem ngayah berdasarkan penilaian dari guru telah mencapai kriteria praktis dan penilaian dari siswa telah dicapai kriteria sangat praktis.

Berdasarkan hasil penelitian dan pembahasan, dapat diajukan beberapa saran sebagai berikut. (1) Bagi guru yang berupaya untuk meningkatkan kompetensi dalam satu kesatuan teori dan praktek, meningkatkan minat siswa belajar keterampilan, serta upaya pelestarian budaya, maka penerapan model pembelajaran kooperatif tipe analogi setting sistem ngayah dapat dijadikan salah satu alternatif jawaban permasalahan tersebut. (2) Produk pengembangan model pembelajaran kooperatif tipe analogi setting sistem ngayah ini dapat disebarluaskan (digunakan) di semua kelas di sekolah yang bersangkutan, atau bahkan di semua sekolah menengah kejuruan di kabupaten Buleleng, namun penyebaran produk pengembangan harus tetap memperhatikan dan memperhitungkan karakteristik dari siswa, sehingga penyebaran produk tidak sia-sia. (3) Kualitas produk pengembangan model pembelajaran ini baru sampai memenuhi kriteria valid dan praktis, sehingga informasi tentang keefektifan model ini belum diketahui dan model pembelajaran yang dikembangkan hanya terbatas pada materi menggunakan perkakas tangan, maka disarankan kepada peneliti lain untuk mengembangkannya pada ruang lingkup materi yang lain dengan kualitas produk pengembangan memenuhi kriteria valid, praktis, dan efektif.

\section{DAFTAR RUJUKAN}

Candiasa, I Made. 2010. Statistik Univariat dan Bivariat Disertai Aplikasi SPSS. Singaraja: Unit Penerbitan Undiksha

Dantes, Nyoman. 2008. "Hakikat Asesmen Otentik Sebagai Penilaian Proses Dan Produk Dalam Pembelajaran Yang Berbasis Kompetensi”. 
Makalah disampaikan pada In House Training (IHT) SMA N Kuta Utara, 2008

Depdiknas, 2003. Undang-Undang Republik Indonesia Nomor 20 Tahun 2003. Tentang Sistem Pendidikan Nasional. Jakarta: Depdiknas

Kustitik. 2016. "Pengembangan Perangkat Penilaian Autentik Mata Pelajaran Prakarya dan Kewirausahaan di SMK". Tersedia pada http://journal.uny.ac.id/index.php/jpv (diakses tanggal 17 Maret 2017).

Mahanal, S. (2007). Portofolio Sebagai Asesmen Otentik. Tersedia pada http://lubisgrafura.wordpress.com/20 07/09/07/portofolio-sebagai asesmenotentik/. (diakses pada tanggal 11 Desember 2017).

Marhaeni, A.A.I.N. 2006. Asesmen Portofolio Dalam Pembelajaran Berbasis Kompetensi. Bahan Pelatihan Bagi Guru-Guru Kabupaten Badung Dan Kota Denpasar Pada Kegiatan Pengabdian Masyarakat Program Pasca Sarjana Undiksha. Singaraja

Nieveen, N. (1999). Prototyping to reach product quality. Dalam J.V.D Akker et. al (Eds), Design approaches and tools in Education and Trainning. Netherlands, Dordsrecht: ICO Cluwer Academic Publisher.

Rusman. 2012. Model-Model Pembelajaran Mengembangkan Profesionalisme Guru. Jakarta : PT Grafindo Persada.

Suherman, E. (2007) Asesmen Portofolio. Educare. Volume 5 Nomor 1, edisi Agustus 2007.

\author{
Suparno, Paul. 2007. Metodologi \\ Pembelajaran Fisika: Konstruktivistik \\ \& Menyenangkan. Yogyakarta: \\ Universitas Sanata Dharma.
}
Trianto. 2012. Mendesain Model Pembelajaran Inovatif Progresif. Jakarta: Kencana Prenada Media Group.

